\title{
Communal Singing as Political Act: A Chorus of Women Resistants in La Petite Roquette, 1943-1944
}

\author{
COLIN ROUST
}

At ten o'clock on a Monday morning in 1941, the courtyards of Paris's La Petite Roquette prison erupted in song. Eighteen young women, all new arrivals who had been arrested about three weeks earlier, led their prisonmates in a rousing rendition of "La Marseillaise." The nuns who managed the prison listened to the performance in respectful, but watchful silence. But when the prisoners began singing "L'Internationale," the nuns flew into action, breaking up the impromptu chorus and forcing the women back to their cells. Exactly one year later, on Bastille Day 1942, the performance was repeated. This time, however, the nuns responded as soon as the first strains of "La Marseillaise" were heard. While punishing the singers, Sister Immaculate Conception, the director of the prison, incorrectly accused the women of singing "L'Internationale." When one of the singers corrected her, she responded "C'est la même chose" (it's the same thing). ${ }^{1}$

Facing the darkest time of their lives, these women faced an indefinite sentence that would, most likely, end with a transfer into the German concentration camp system. All former fighters in the French Resistance, they were now prevented from taking direct, physical action against the Nazi occupiers. Instead, they turned to song as a means of proclaiming their identity and demonstrating their political beliefs. Through songs such as "La Marseillaise" and "L'Internationale," this group of women proclaimed that although they had been captured, they certainly had not been defeated.

The story of the women's chorus in La Petite Roquette offers a potent complement to current scholarship on the music of the French Resistance. The bulk of that work has been conducted only in the past twenty years, by a mixture of French and American scholars. With one prominent exception drawn

from an archival collection of some ten thousand songs sung during the German Occupation, ${ }^{2}$ the existing literature focuses exclusively on the activities of a small organization known as the Front National de la Musique. ${ }^{3}$ Like the other groups that made up the communist "National Front," this was an informational

\footnotetext{
This article is based on presentations given at the Annual Meeting of the American Musicological Society and colloquium series at Case Western Reserve University, Oberlin College, and the University of Iowa. I am grateful to Jack Curtis Dubowsky, Louis Epstein, Kendra Leonard, Rebecca Marchand, and Ana Alonso Minutti for their helpful and critical comments on earlier drafts of this text.

${ }^{1}$ France Hamelin, Femmes dans la nuit: L'Internement à La Petite Roquette et au Camp des Tourelles, 1939-1944(Paris: Renaudot, 1988); reissued as Femmes en prison dans la nuit noire de l'occupation: Le Dépôt, La Petite Roquette, le Camp des Tourelles (Paris: Editions Tirésias, 2004), 186.

${ }^{2}$ Thierry Barthoulot, Paroles et musique: Les Chansons et la Deuxième guerre mondiale (Besançon: Musée de la Résistance et de la Déportation, 2003). The archive in Besançon was created by Barthoulot by calling for documentation of any songs that were sung in France during the years of the German Occupation. It includes published sheet music, original music manuscripts, and thousands of handwritten contrafacta. The songs included are a mixture of resistance, collaborationist, and apolitical songs.

${ }^{3}$ Jane Fulcher, Renegotiating French Identity: Musical Culture and Creativity in France during the German Occupation (forthcoming); Fulcher, "French Identity in Flux: The Triumph of Honegger's Antigone," Journal of Interdisciplinary
} 
network organized around a single industry. Several of these represented the core of the intellectual resistance: specifically the National Fronts of writers, musicians, the cinema industry, and the theater industry. In this case, the network was fairly small, with only thirty-six members at its peak. ${ }^{4}$ Yet its members included many of the most illustrious musicians in 1930s France: Georges Auric edited the group's clandestinely published journal; he was joined on the executive committee by the composers Elsa Barraine, Louis Durey, Francis Poulenc, and Arthur Honegger; the conductors Charles Munch and Roger Désormière; and the director of the Paris Conservatoire, Claude Delvincourt. The group's activities included organizing a couple of concerts honoring Darius Milhaud, who had escaped to San Francisco. Several members also wrote a few compositions expressing Resistance sentiments, most notably Auric's Quatre Chants de la France Malheureuse and Poulenc's song "C" and cantata La Figure Humaine. However, the actual reach and effectiveness of the group was limited by the size of the group and the elite artistic stature of its members; these were simply not the same people who would be bombing trains, bridges, and factories. The relative isolation of their musical works and arguments from the more actionoriented network leaves the question of what music mattered to other Resistance groups, beyond the Front National de la Musique? Why was that music significant to them? And how did they use that music?

However, music was an ephemeral part of the Resistance's clandestine activities. The most common primary sources are postwar memoirs and accounts by members of the Resistance, along with the documentation of the Fourth Republic's audit to identify who collaborated with the Germans and who fought in the Resistance. ${ }^{5}$ These sources primarily answer the questions of who took action against the Occupation, what action they took, and where and when the action took place. Rarely are there accounts of culture within the Resistance. When music is mentioned, it is almost always a brief mention of "La Marseillaise," "Vive la vie, vive la joie et l'amour," or Anna Marly's "Le Chant des Partisans." But there are exceptions, and this project emerged from one of them. While combing through a box of clandestinely published sheet music, I came across a small black notebook that documented songs sung in Paris's La Petite Roquette prison during the last six months of the Occupation. This songbook offers tangible evidence of the musical practices of one group of women resistants. But before examining the notebook itself, we must understand what daily life was like for these women and how music fit into it.

History 36 (Spring 2006): 649-74; Julian Jackson, France: The Dark Years 1940-1944(Oxford: Oxford University Press, 2001); Guy Krivopissko and Daniel Virieux, “Musiciens: Un profession en résistance?,” in La Vie musicale sous Vichy, ed. Myriam Chimènes (Paris: Editions Complexe, 2001); Colin Roust, "Sounding French: The Film Music and Criticism of Georges Auric, 1919-1945,” PhD diss., University of Michigan, 2007; Roust, “Toward an Aesthetic of Resistance: Georges Auric's Quatre Chants de la France malheureuse," Ars Lyrica 18 (2009): 157-72; Nigel Simeone, “Messiaen and the Concerts de la Pléiade: 'A Kind of Clandestine Revenge against the Occupation!'," Music and Letters 81, no. 4 (2000): 551-84; Simeone, "Making Music in Occupied Paris," Musical Times, no. 1894 (2006): 23-50; Virieux, "Front National des Musiciens (printemps 1941-automne 1944)," in Roger Désormière, 1898-1963: Actes du colloque, ed. Nicolas Guillot (Paris: Comité pour la célébration du centenaire de la naissance de Roger Désormière, 1999).

${ }^{4}$ The surviving documents for the Front National de la Musique are preserved at the Musée de la Résistance Nationale in Champigny-sur-Marne, France. Krivopissko and Virieux have summarized these in their article, "Musiciens: Un profession en résistance?”

${ }^{5}$ One of the most important archival collections of this sort is the Fonds de Liquidation des Mouvements OS-FN-FTP at the Musée de la Résistance Nationale, which are examined in detail in Daniel Virieux, "Le Front national de lute pour la liberté et l'indépendance de la France: Un mouvement de résistance, période clandestine (mai 1941-août 1944)" (thèse de doctorat, Université de Paris 8, 1995).

${ }^{6}$ See for example Floriane Benoit and Charles Silvetre, eds., Les Inconnus de la Résistance: Livre d'un Témoignage Collectif (Paris: L'Humanité and Editions Messidor, 1984). 


\section{A Brief History of La Petite Roquette}

In 1825, the Assemblée Nationale announced a competition to design a model prison that, "with the aid of a central point or internal gallery . . can be supervised by one person, or at the most two people."7 The winning entry was submitted by Charles Lucas, who later published his proposal in a two-volume study of European and American prisons. ${ }^{8}$ He suggested adopting the principles of Jeremy Bentham's penitentiary system, in which prisons were conceived as places of penitence and reform, rather than punishment and death. ${ }^{9}$ In the final two sections of his proposal he outlined a program of reform and presented a detailed sketch of his ideal prison: It would hold four hundred women prisoners, relieving the overcrowding in the Prison Saint-Lazare, Paris's primary women's prison at the time. It would be built as a hexagonal ring, with six spokes emanating from a central ring (see figure 1). Two sides of the hexagon would feature administrative offices and sleeping quarters for the guards. The ground floor of each spoke would be reserved for dining spaces and workshops. The upper floors of the hexagon and the spokes would consist of seven-and-a-half foot square cells for individual prisoners, with nine-foot high ceilings. The central tower would have the kitchen, chapel, infirmary, visiting room, and a panopticon observation room.

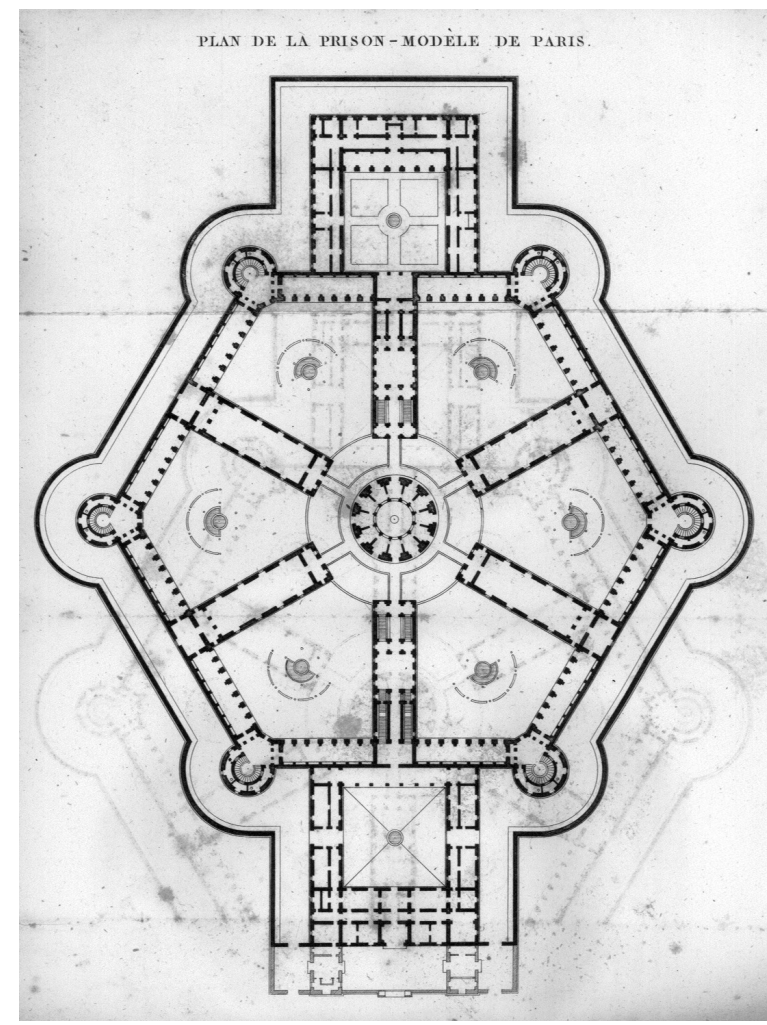

Figure 1: Charles Lucas's proposed design of a model prison. Lucas, Du système pénitentiaire, insert following page cxv.

\footnotetext{
${ }^{7}$ Michel Foucault quotes the February 24, 1825, circular in "28 November 1973," Psychiatric Power: Lectures at the Collège de France, 1973-1974, ed. by Jacques Lagrange, trans. by Graham Burchell (New York: Picador, 2006), 90 n.18.

${ }^{8}$ Charles Lucas, Du système pénitentiaire en Europe et aux Etats-Unis: Ouvrage dédié aux Chambres, précédé d'une pétition qui leur est addressée, et orné de plusieurs plans de prisons et tableaux statistiques (Paris: Editions A. Bossange and Editions Charles Béchet, 1828-1830), 1: i-xxxvii.

9 Jeremy Bentham, Panopticon, or the Inspection-House, in The Panopticon Writings, ed. by Miran Bozovic (London: Verso, 1995), 29-95.
} 
Between the tower and the guard posts in each corner of the hexagon, inmates could be observed at all times with minimal staff_-an essential point for Bentham's panopticon system, which operated by disrupting the see/being seen dyad. The guards can see every prisoner, but their observation points are obscured by one of several means (venetian blinds, black paint, etc.), so that the prisoners cannot see the guards. ${ }^{10}$ The prisoners know that they are constantly visible to the guard posts, though they are unable to determine whether they are actually being watched at any given moment. As Michel Foucault noted in Discipline and Punish: The Birth of the Prison, the panopticon system

makes it possible to perfect the exercise of power. It does this in several ways: because it can reduce the number of those who exercise it, while increasing the number of those on whom it is exercised. Because it is possible to intervene at any moment and because the constant pressure acts even before the offences, mistakes or crimes have been committed. Because, in these conditions, its strength is that it never intervenes, it is exercised spontaneously and without noise, it constitutes a mechanism whose effects follow from one another. Because, without any physical instrument other than architecture and geometry, it acts directly on individuals; it gives "power of mind over mind." The panoptic schema makes any apparatus of power more intense: it assures its economy (in material, in personnel, in time); it assures its efficacity by its preventative character, its continuous functioning and its automatic mechanisms. ${ }^{11}$

The strength of Lucas's proposal—and undoubtedly some of the justification for accepting it—relied on these advantages: here was a means of dealing with criminals that was morally, economically, and judicially superior to the dungeon-like prisons that made up the Parisian penal system in the early nineteenth century. For the women who sang in the courtyards during World War II, it also meant that they could be certain their actions were seen. Their songs were thus not only a performance for themselves, but a demonstration made under the watchful eyes of the panopticon.

After the Assemblée Nationale accepted Lucas's proposal, Louis-Hippolyte Lebas was commissioned as the architect. A location was found on the rue de la Roquette, in Paris's eleventh arrondissement and construction began in 1826. The work was essentially complete a few months after the 1830 July Revolution, though the prison did not actually open until 1836. In 1830 the newly installed "citizen king," Louis-Philippe, also commissioned another new prison from Lebas, to be built across the street from Lebas's first prison. Based on a different design, this massive square edifice would house those male prisoners who had committed the most serious crimes. This second prison, also opened in 1836, would be the site of Parisian executions until its 1899 demolition, prompted by considerable opposition to the death penalty by the intellectual elite (see figure 2). Because of their location and relative sizes, the two prisons became known, respectively, as La Petite Roquette and La Grande Roquette.

\footnotetext{
${ }^{10}$ A photograph of the view from one of the corner guard posts is available at http://gallica.bnf.fr/ark:/12148/btv1b90217403.

${ }^{11}$ Michel Foucault, Discipline and Punish: The Birth of the Prison, trans. by Alan Sheridan (New York: Vintage Books, 1995), 206.
} 


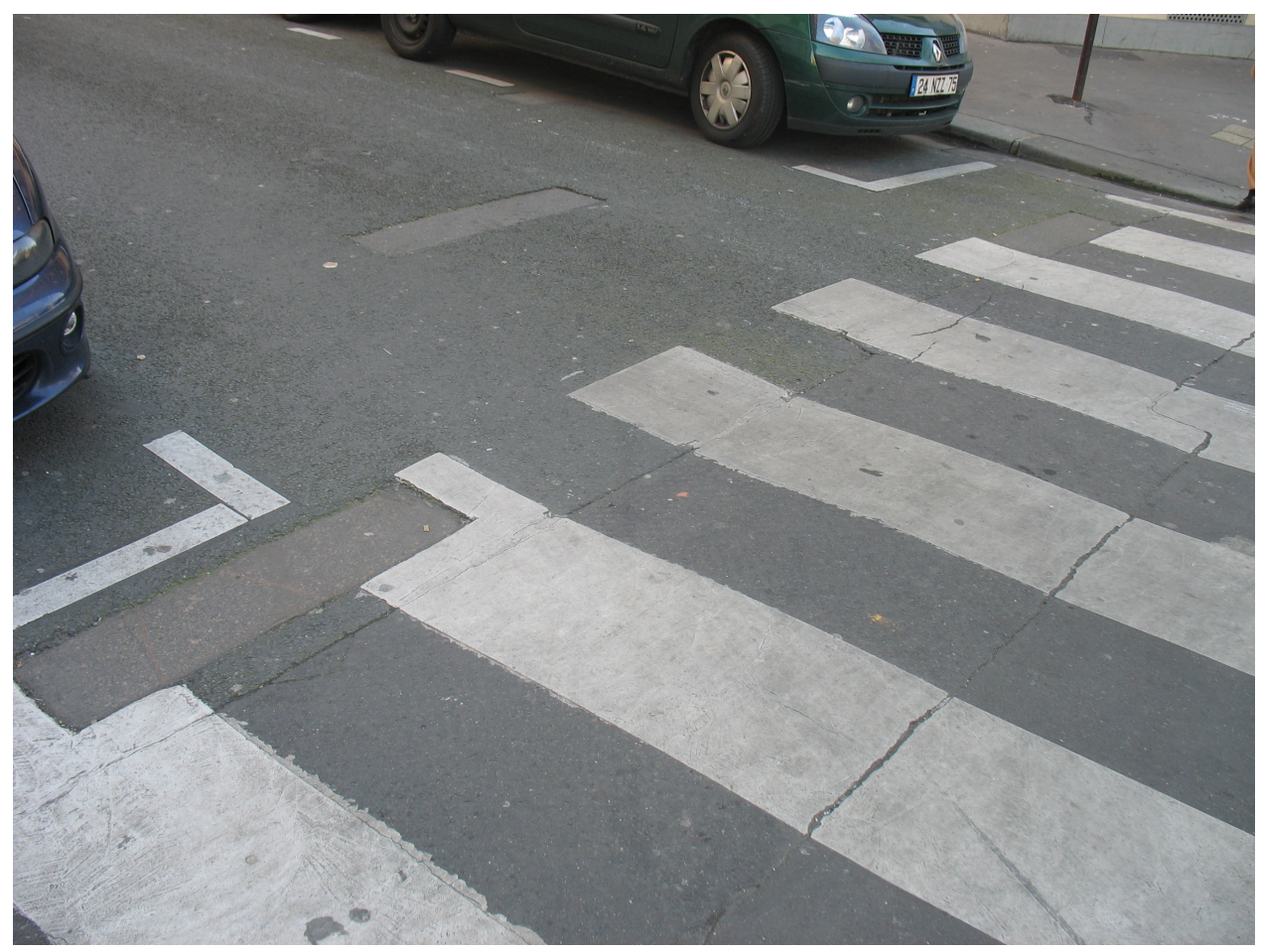

Figure 2: The last remnants of La Grande Roquette, the foundation stones from the guillotine that was used for public executions from 1836 until 1899. These stones can be seen in the rue de la Crois Faubin, just south of its intersection with rue de la Roquette. Photo by Cédric Gravelle, used under a Creative Commons Attribution-Share Alike license. Available at: http://commons.wikimedia.org/wiki/File\%3ADalle guillotine_roquette.jpg

Though Lucas had proposed that La Petite Roquette be a women's prison, it would function instead as a juvenile prison from 1836 until 1865. Initially, the prison operated in accordance with Lucas's penitentiary plans: during the days, prisoners could interact with each other in the courtyards, classes, workshops, and chapel; during the nights, they were each locked into their individual cells. In 1840, however, the program was changed to one of strict discipline and isolation. The juvenile prisoners spent their whole day in their cells: teachers visited each student for individual instruction and staff delivered meals to each individual. The prisoners were only allowed out of their cells to attend chapel, during which each was placed in his own box, so he could see the priest but was unable to see other prisoners, and for exercise, during which each was placed in one of several individual, walled-off exercise yards arranged in a semicircle around a panopticon guard post. ${ }^{12}$ By 1865, public outcry over the harsh conditions in La Petite Roquette finally resulted in change. For the next sixty-seven years, La Petite Roquette would be a receiving prison for juvenile and adult detainees awaiting trial at the Palais de Justice. Though poorly maintained during its decades as a receiving prison, it became the city's primary women's prison in 1932, following the

\footnotetext{
${ }^{12}$ A photo of the chapel, taken from the ambo can be seen at http://gallica.bnf.fr/ark:/12148/btv1b90217470; note that in this image, the doors to each box are open. Another image, taken from the left side of the chapel can be seen at http://gallica.bnf.fr/ark:/12148/btv1b90217529. A photo of the exercise yards, taken from the panopticon can be seen at http://gallica.bnf.fr/ark:/12148/btv1b90217455; each yard would have been approximately 10 to 15 meters long.
} 
demolition of the Prison Saint-Lazare. ${ }^{13}$ It would function in this capacity until its demolition in $1975 .{ }^{14}$ Today, the former site of La Petite Roquette has been converted into the largest park in the eleventh arrondissement, the Square de la Roquette (see figure 3). All that remains of the prison are the sentry boxes that guarded the entrance, which today provide the main entrance to the park (see figure 4) and a plaque commemorating the members of the French Resistance who were incarcerated there (see figure 5).

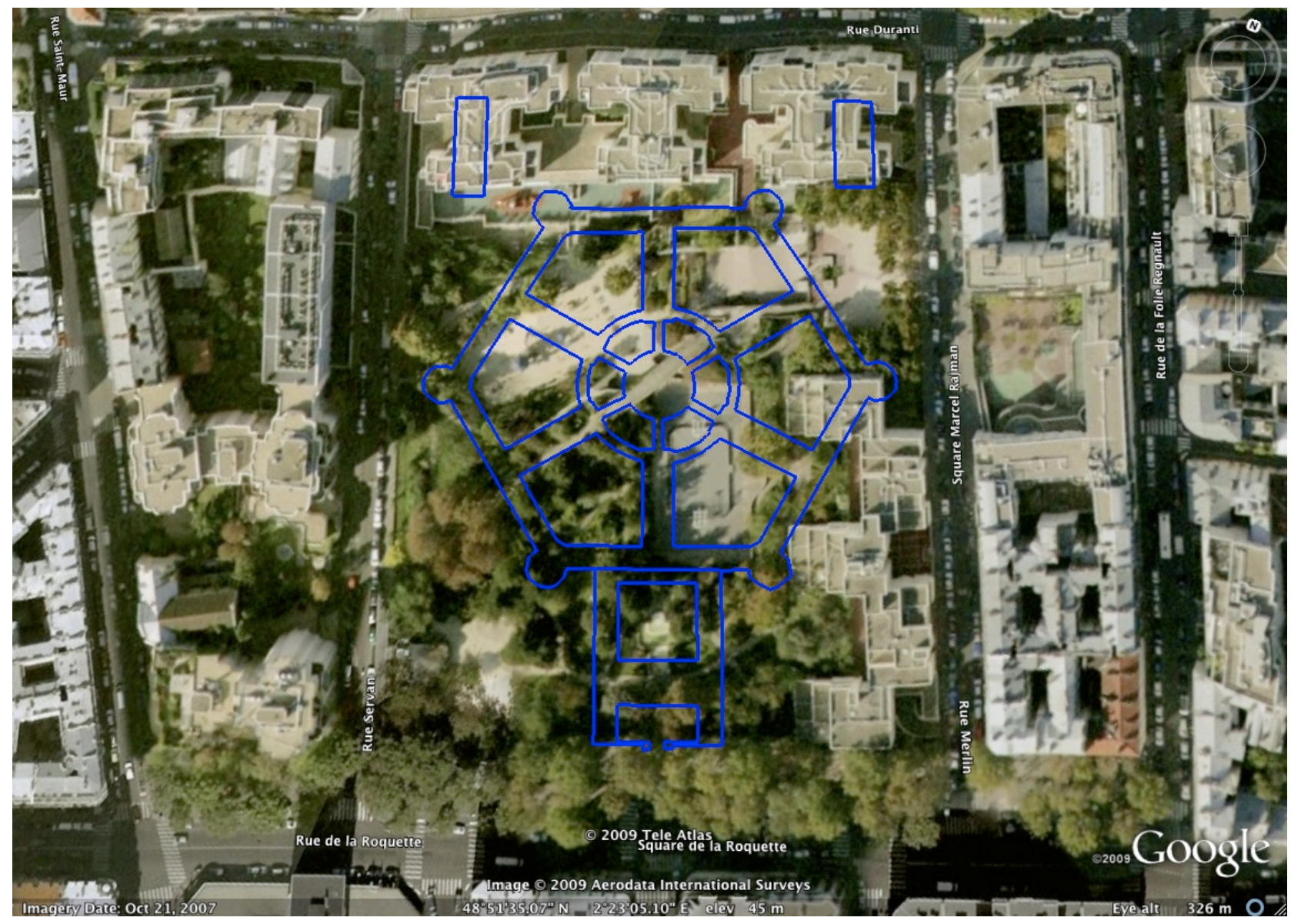

Figure 3: The footprint of La Petite Roquette superimposed on a satellite image of the Square de la Roquette. The footprint reflects the state of the facility during its use as a women's prison. The two outer buildings to the north were bunkhouses for the guards, which were built when the isolated exercise yards were demolished. Satellite image courtesy of GoogleMaps.

\footnotetext{
${ }^{13}$ For a more detailed history of the prison and, especially, of the published criticisms of it, see Marie-Noelle Barbaroux and Jocelyne Broussard, "L'évolution historique de La Petite Roquette," Rééducation 191 (May 1967): 2-41; and Henri Gaillac, Les Maisons de correction, 1830-1945 (Paris: Editions Cujas, 1991), 61-68.

${ }^{14}$ During the 1960s, there were several television programs and segments about La Petite Roquette, beginning with "Prisons de femmes," an episode of La Justice des Hommes that aired on January 29, 1960 (available at http://www.ina.fr/video/CPF86608996). On November 12, 1967, an episode of Dim, Dam, Dom featured author Marguerite Duras interviewing the directrice of the prison (http://www.ina.fr/video/CPF07006187). On May 6, 1968, an episode of Les femmes aussi entitled "Odette et la prison" featured a dramatization based on a true story of one woman's experience during and after her time in La Petite Roquette (http://www.ina.fr/video/CPF86630552).
} 


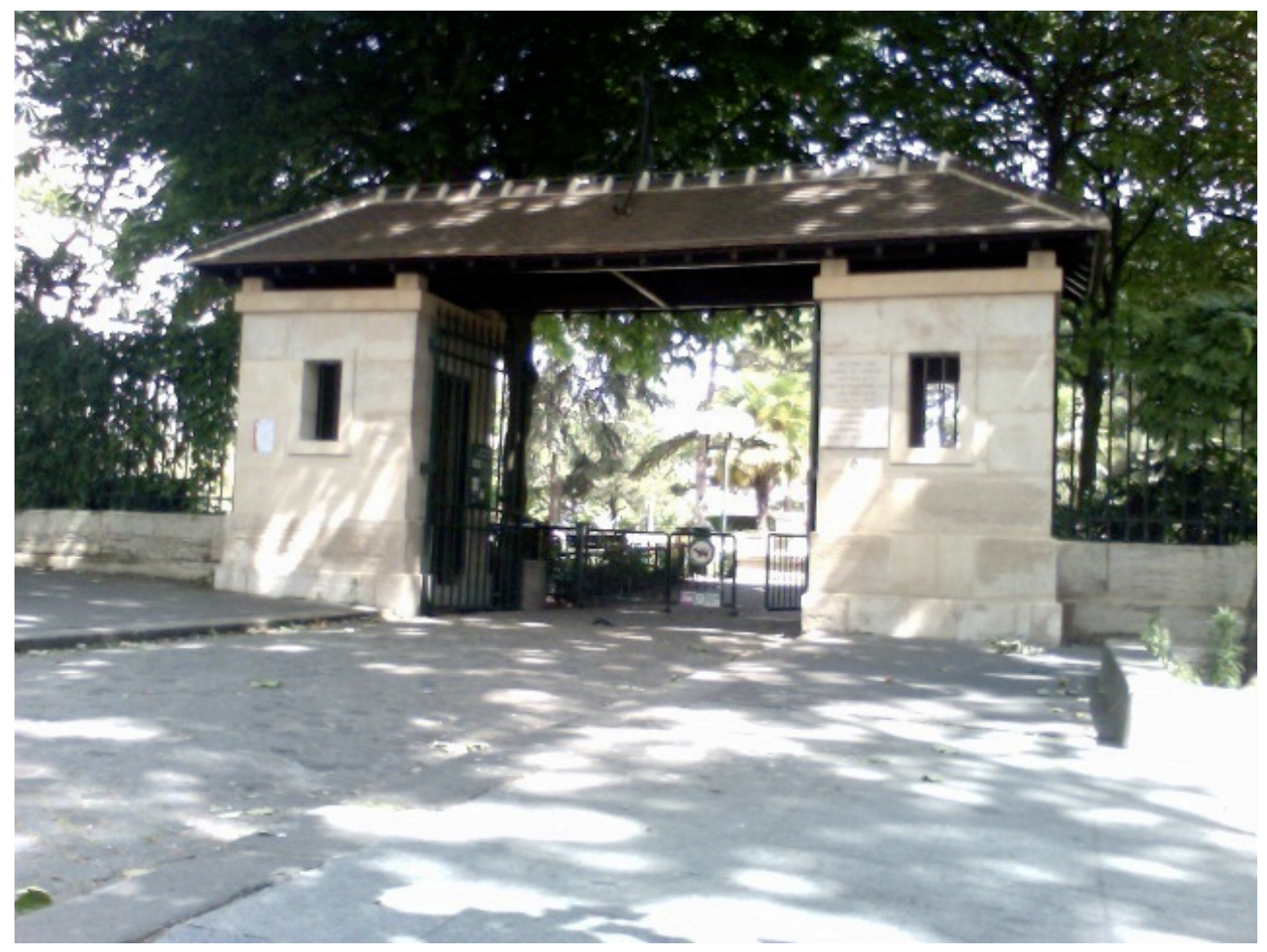

Figure 4: The sentry boxes at the main entrance of La Petite Roquette. Photo by the author.

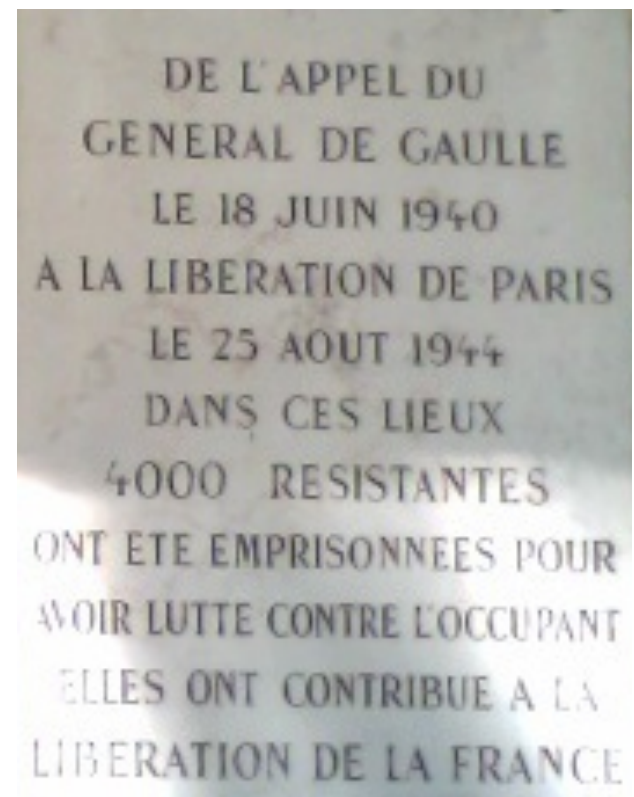

Figure 5: Plaque commemorating the members of the French Resistance imprisoned in La Petite Roquette. "From the call of General de Gaulle on June 18, 1940, to the liberation of Paris on August 25, 1944, four thousand women resistants were imprisoned here for fighting against the Occupier. They contributed to the liberation of France." Photo by the author. 


\section{Daily Life in La Petite Roquette during the German Occupation}

Two of the women imprisoned in La Petite Roquette between 1942 and 1944 later wrote accounts of their daily lives, giving a striking sense of the social structure and daily routines within the prison. Yvette Semard, whose father had been a prominent leader in both labor unions and the French Communist Party, was arrested on February 1, 1942, when a police search of her apartment turned up a single issue of a clandestine communist newspaper. ${ }^{15}$ She spent two months in La Petite Roquette before being transferred through a series of five French internment camps; ultimately she escaped from the Camp de Mérignac on May 15, 1944. France Hamelin, on the other hand, was an active member of the FrancsTireurs et Partisans and, along with her husband, Lucien, was arrested on August 31, 1943, for participating in various sabotage missions. ${ }^{16}$ While her husband was deported to the Buchenwald concentration camp, she was allowed to stay in Paris since she was pregnant. Her son was born on April 15, 1944, but due to medical complications they spent the next month in the Hôpital Tenon, from which she escaped in mid-May. ${ }^{17}$

When La Petite Roquette was converted into a women's prison in 1932, the cells that had been designed originally for one person now housed two. By 1943, every cell held four or five-typically two droits communs (common law criminals) and two or three droits politiques (political criminals), generating significant tensions between the two types of prisoners. There were not enough beds to go around and the common law criminals were given priority, so many of the political criminals slept on pallets on the floor. The common law criminals, many of whom were repeat offenders, tended to see the political prisoners as the reason for the overcrowding. Generally speaking the common law criminals were less interested in the politics of the Resistance, so they tended to separate themselves from the others. The common law criminals served fixed sentences, after which they were released. The political criminals, on the other hand were not tried—some were not even told why they had been arrested—and they would not know their fates until the war was decided. ${ }^{18}$ Almost all of them were ultimately transferred into the German concentration camp system.

While there were police guards in the prison, almost all contact with the women was through the Sisters of Marie-Joseph, a French order of nuns whose mission is to minister to prisoners. ${ }^{19}$ Thus, at 6:00 a.m., some of the nuns woke up the women and hurried them toward the washroom. Another nun timed them as they washed up in sinks-showers were only permitted for those infested with scabies. From there, the nuns marched them into one of the courtyards or one of the cafeterias, where they received a

\footnotetext{
${ }^{15}$ In her account of the arrest, she notes that there was much more that the police could have found-she was, after all, a member of the French Resistance, though the police did not know this-but that a single issue of the newspaper was sufficient grounds for her arrest. The police secured her arrest warrant on the grounds of her family's ties to the French Communist Party (her father was already in prison and would be executed on March 7, 1942) and on her own leadership within the Union des Jeunes Filles de France, a constituent organization of the Young Communist Movement in France from 1936 to 1956. Yvette Semard, En souvenir de l'avenir: Au jour le jour dans les camps de Vichy (1942-1944)(Montreuil:

L'Arbre Verdoyant, 1991), 5 and 9-11.

${ }^{16}$ France Hamelin, Femmes en prison dans la nuit noir de l'occupation: Le Dépôt, La Petite Roquette, le Camp des Tourelles (Paris: Editions Tirésias, 2004).

17 “L'évasion d'un nouveau-né," Le Patriote Résistant (October-December 1948; reprinted in April 2007), available at http://www.fndirp.asso.fr/france\%20hamelin.htm.

${ }_{18}^{18}$ Social life in the prison has been extensively documented by France Hamelin, who was matriculated there on August 31, 1943, and later transferred to the Camp des Tourelles, from which she escaped with her newborn son on about April $28,1944$.

${ }^{19}$ For more on the relationships and interactions between the nuns and the prisoners, see Hamelin, Femmes en prison, $172-$ 184; and Semard, En souvenir de l'avenir, 17-18.
} 
piece of dark bread and a bowl of tisane, a marginally nutritious soup. ${ }^{20}$ During the mornings and evenings, the women were always welcome in the chapel. In the ground-floor workshops, they were taught practical skills and they made crafts like handbags and dolls. Finally, until about October or November 1943, the women were allowed during the daytime to socialize in one of the two courtyards on either side of the spoke in which they were housed, though only during certain hours, since silence was imposed on the prisoners throughout most of the day. In late 1943, however, the women successfully lobbied the nuns to be allowed to move between all six of the prison's courtyards. Any activities in these courtyards, however, were carefully watched from the panopticon observation room atop the central tower. ${ }^{21}$ Thirty years later, shortly before the prison's 1974 demolition, some of them returned for one last visit, noting that hardly anything had changed:

[Some of the cells] remained in the state in which we had known them: dirty black walls, humidity oozing from all the pores of their plaster, and crumbling bit by bit. A timid ray of sunshine flowed between two bars and made a bright spot on the ground, almost unseemly in this domain of ruin. I saw us, sleeping five or six on the notorious palettes or even lying on the cement. The bedbugs seemed to make them move. Now these cells are no longer used, they tell me: a portion of the cells which are occupied have even been renovated. ${ }^{22}$

Among the political prisoners in La Petite Roquette were representatives of at least six Resistance networks sponsored by the French Communist Party: Forces Unies de la Jeunesse Patriotique, FrancsTireurs et Partisans, Front Patriotique de Jeunesse, Jeunes Filles de France, J3, and Main-d'Oeuvre Immigrée. These women played a key role in the daily life of their fellow inmates. They served as a welcome wagon of sorts for new prisoners and distributed two hand-made newsletters, La Patriote Enchainée and Confiance-Lutte-Espoir. ${ }^{23}$ In addition, they organized a variety of entertainments, such as singing, poetry recitations, and even semi-staged performances of plays (most notably works by Molière, recited entirely from memory).

Hamelin recounts in her memoir that the musical life of the women resistants in La Petite Roquette began on Bastille Day, 1941, with the musical demonstration described at the beginning of this article. With this act—and similar demonstrations on November 11, 1941 (the anniversary of the Allied victory over Germany in World War I), and Bastille Day, 1942, the women of La Petite Roquette inaugurated a tradition of musical protests that would last until the Liberation of Paris in August 1944. In 1943, the women even managed to form an ad hoc chorus that met every afternoon, though these gatherings were generally broken up by charging nuns brandishing large sticks. Many of the women would continue singing when they were transferred to other prisons: either to Les Tourelles, a converted military barracks in the twentieth arrondissement, or via the fortress at Romainville in the Parisian suburbs to the German concentration camp system (see figure 6). For these women-and for the Sisters of Marie-Joseph who maintained order in the prison - this act of communal singing was understood as a declaration of their political identity and as an act of resistance.

\footnotetext{
${ }^{20}$ Hamelin, Femmes en prison, 144-145; and Semard, En souvenir de l'avenir, 15.

${ }^{21}$ Hamelin, Femmes en prison, 131-135.

22 Jackye Brun quoted in Hamelin, Femmes en prison, 133.

${ }^{23}$ Hamelin, Femmes en prison, 190-193.
} 


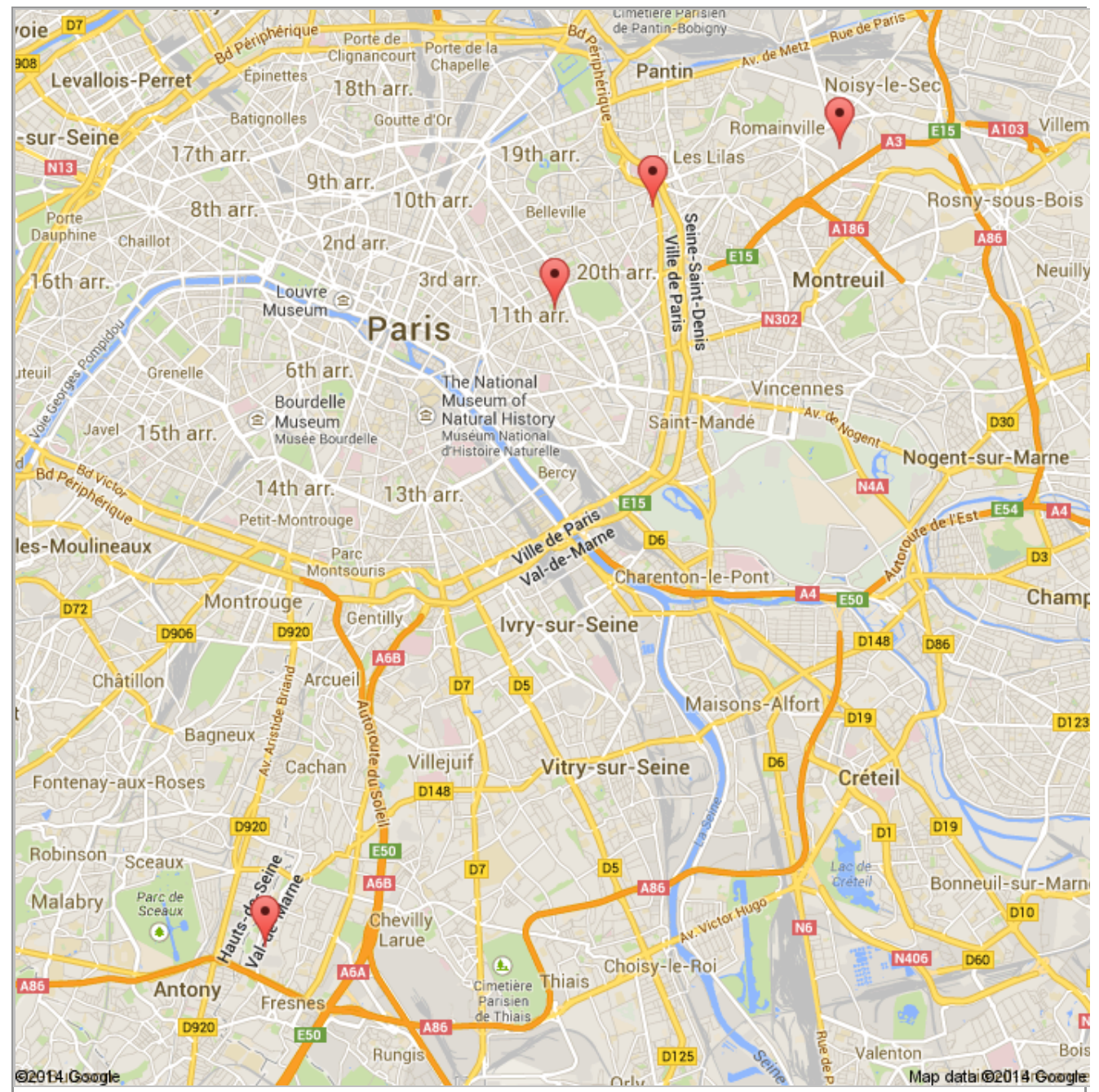

Figure 6: Map of women's prisons in Paris during the Occupation (http://goo.gl/maps/D7dPB)

\section{The Songs of La Petite Roquette}

In the collections of the Musée de la Résistance Nationale there is a small, well-worn black notebook that was given to the archive in the 1970s. Inside the cover is a handwritten note identifying it as a "song book made in La [Petite] Roquette from February 1944 to August 1944" (see figure 7). Since the author, Christiane Poinsch Famery was deported to Germany on the last train out of Paris, this songbook documents the culmination of the Resistance musical activity in the prison. ${ }^{24}$ The pages of the notebook are filled with the texts of twenty-two songs. With one exception, the songs are written out in their entirety; as France Hamelin proudly noted in her account of the prisoners, the chorus in La Petite Roquette sang all eight verses of "La Marseillaise" - an unusual practice, even in France. ${ }^{25}$ The one exception is the "Chant des adieux," which is missing part of the refrain and three verses (see figure 8).

\footnotetext{
${ }^{24}$ For another study of similar musical activities, see Brett Werb and Barbara Milewski, "From 'Madagaskar' to Sachsenhausen: Singing about 'Race' in a Nazi Camp," in Polin: Studies in Polish Jewry, vol. 16 "Jewish Popular Culture and Its Afterlife," ed. by Michael C. Steinlauf and Antony Polonsky (Oxford: Littman Library of Jewish Civilization, 2003): 269_ 278.

${ }^{25}$ Hamelin, Femmes en prison, 194.
} 
Based on her note in the front cover of the book, it would seem that Famery was in the process of writing down the songs at the time she and 101 of her prisonmates were rounded up in trucks and driven to the Gâre de Pantin, where they were loaded onto a train bound for the Neue Bremm concentration camp in Saarbrücken (see figure 9). ${ }^{26}$ The repertoire recorded in Famery's songbook was drawn from songs the women had learned in schools and summer camps, from the Scouting movement, and from a variety of communist and Soviet sources (see figure 10). Through these songs, we can gain a clearer sense of the women's personal and political identities. ${ }^{27}$

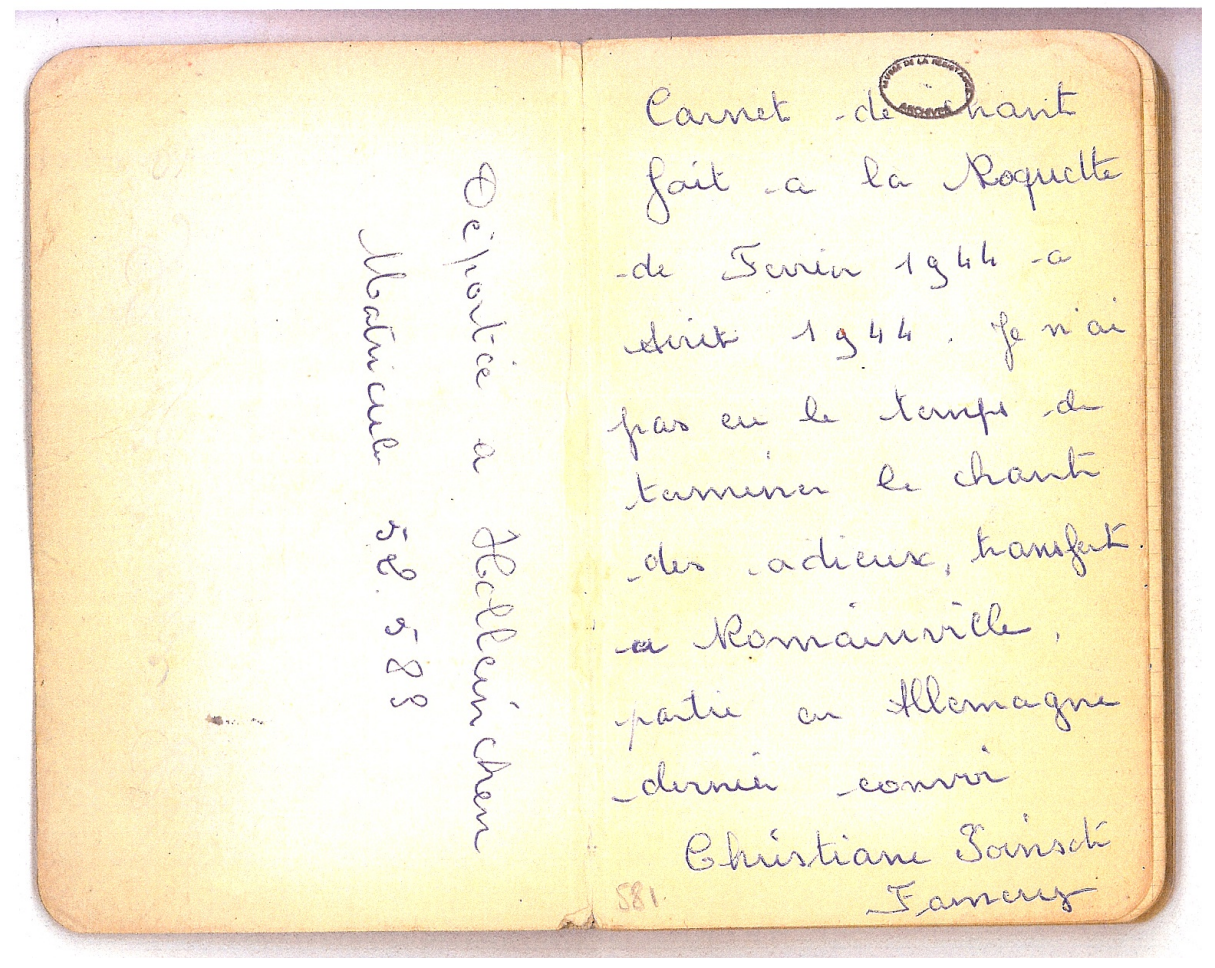

Figure 7: The inside cover of Christiane Poinsch Famery's songbook. The left-hand page reads "Deported to Holleischen. Matriculation 52583." The right-hand page reads "Song book made at la [Petite] Roquette from February 1944 to August 1944. I didn't have time to finish the 'Chant des Adieux,' transferred to Romainville, left for Germany last convoy. Christiane Poinsch Famery.” @Musée de la Résistance Nationale à Champigny-sur-Marne.

\footnotetext{
${ }^{26}$ Michel Reynaud, ed., Livre-Mémorial des déportés de France arrêtes par mesure de répression et dans certains cas par mesure de persécution, 1940-1945, vol. 3 (Paris: Editions Tirésias, 2004), 85-90. Famery's record in this catalog, listed under her maiden name Levasseur, provides the following information: She was born in St. Dizier on April 9, 1917. After her imprisonment in La Petite Roquette, she was transferred to the Romainville prison. On August 11, 1944, she and 101 other women were transferred to the Neue Bremm camp, via a train journey that lasted for six days. The women ultimately arrived at Ravensbrück concentration camp on August 26, where Famery's matriculation number was \#52583. From there, the women were distributed among at least five labor and extermination camps. Famery and at least thirty-nine others were sent to work at the Holleischen concentration camp, where they were liberated on May 4, 1945.

${ }^{27}$ The ensuing discussion focuses primarily on the texts and contexts of these songs in order to avoid any unwarranted speculation about how the women sang these songs. For example, there is no evidence as to whether everybody sang the melody or whether the group sang in harmony. Famery's notebook contains only the titles and texts-and in many cases, these are different than other versions of the songs that would have been better known in France at the time.
} 


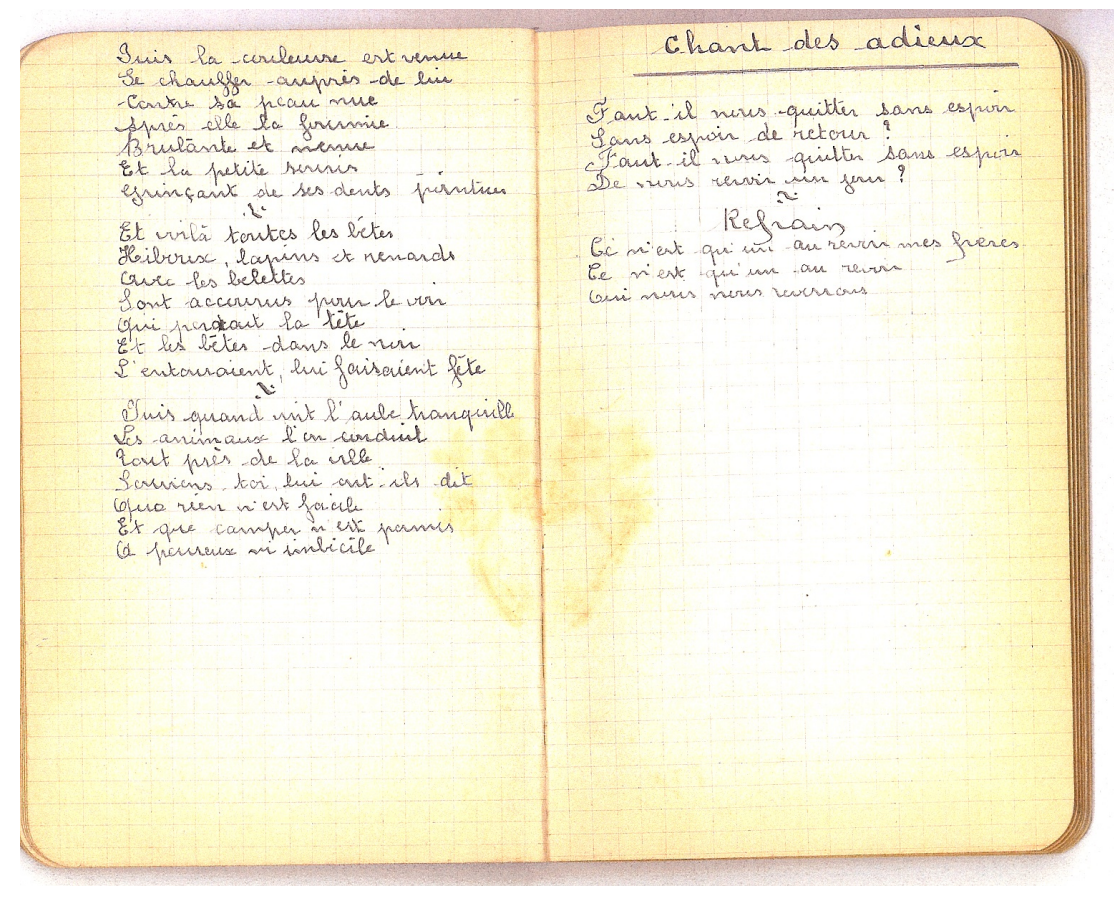

Figure 8: Verses four through six of Georges Auric's "Le campeur en chocolat" (left) and the first verse and part of the refrain of the "Chant des adieux" (right). COMusée de la Résistance Nationale à Champigny-sur-Marne.

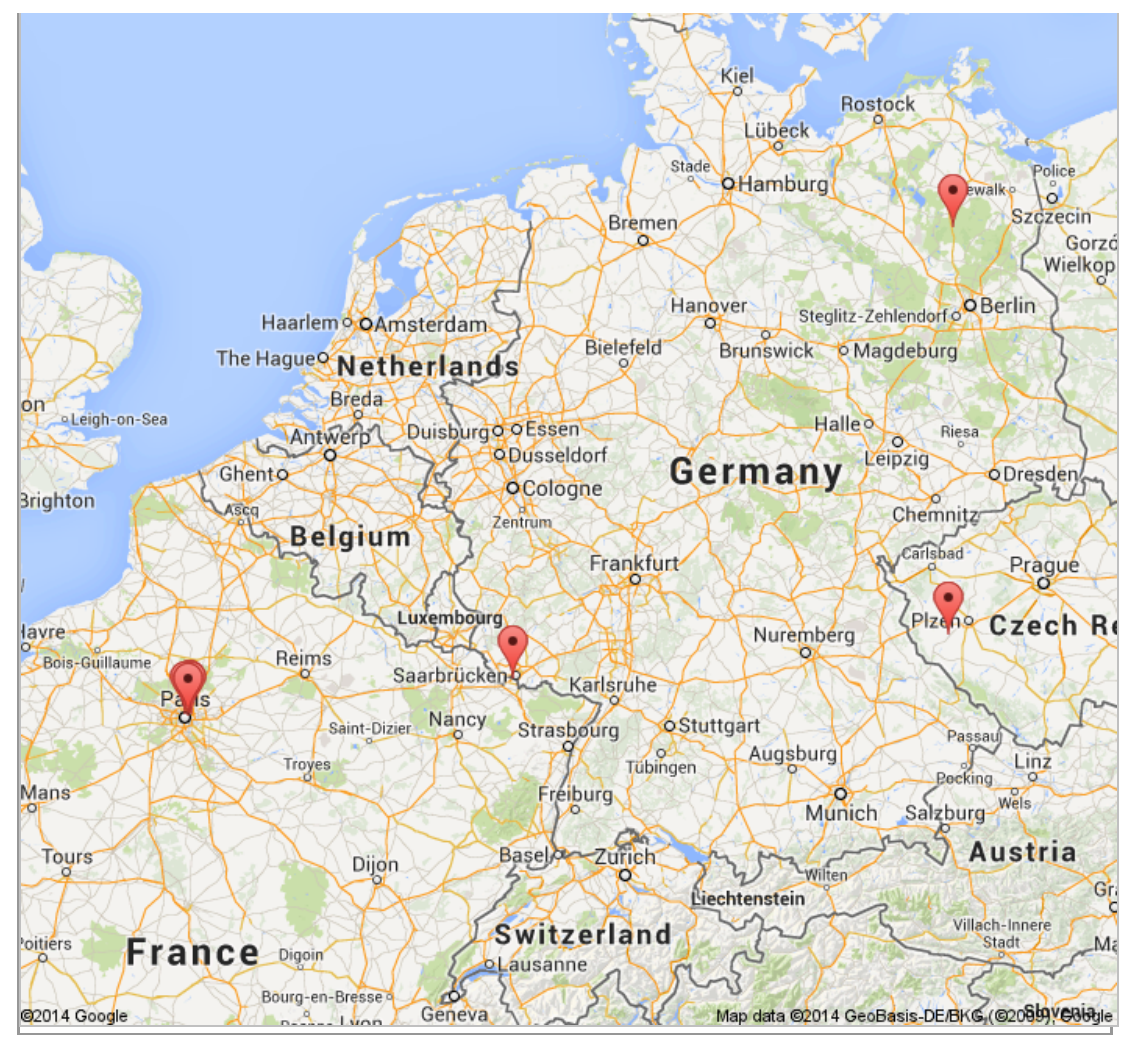

Figure 9: Map of Christiane Poinsch Famery's path from La Petite Roquette through the German concentration camp system. (http://goo.gl/maps/BngPD) 


\begin{tabular}{|c|c|}
\hline Page & Song Title \\
\hline 1 & "Les cavaliers de la Steppe" \\
\hline 2 & "Chant des pilotes" \\
\hline 3 & "Chant des aviateurs" \\
\hline 3 & "Chant du Turkmenistan" \\
\hline 4 & "La Komsomolsk" \\
\hline 5 & "Vive la vie" \\
\hline 6 & "Magnitogorsk" \\
\hline $7-8$ & "Camarade Fideleiv" \\
\hline 9 & "Chant de la Cavalerie" \\
\hline 10 & "La vieille ronde" \\
\hline 11 & "Les Moissonneurs" \\
\hline 12 & "L’hymne à la joie" \\
\hline $13-14$ & "Le chant des survivants" \\
\hline 15 & "Le bon vent" \\
\hline 16 & "L'hiver sera bientôt passé" \\
\hline $17-18$ & "Jeunesse de France" \\
\hline 19 & "Les 3 princesses" \\
\hline 20 & "Souliko" \\
\hline 21 & "Quand nous marchons" \\
\hline 22 & "Stenka Razine" \\
\hline $23-24$ & "Le campeur en chocolat \\
\hline 25 & "Chant des adieux" \\
\hline
\end{tabular}

Figure 10: Contents of Christiane Poinsch Famery's songbook. (OMusée de la Résistance Nationale à Champigny-sur-Marne.

France Hamelin, who sang in the chorus, noted that the singers consisted almost entirely of the younger prisoners and were led by Raymonde Boix. ${ }^{28}$ Given the ages reported in Reynaud's catalogue of deportees, the women were likely in their twenties and thirties; Famery's twenty-seventh birthday was in April 1944 and Boix turned twenty-four the following June. ${ }^{29}$ This youthfulness is reflected in ten songs drawn from the repertoire of French girls' schools, summer camps, and the French Scouting Movement. Two of these songs are of particular interest in this regard: "Le campeur en chocolat" and "Jeunesse de France" were written for children who attended the thousands of summer camps established by the Popular Front and related leftist organizations between 1936 and 1938. ${ }^{30}$ Both songs were published in 1937 by the left-leaning Fédération Musicale Populaire in a series that aimed to introduce children to music written by the leading composers of the day. In addition to "L'Internationale," this series of campfire songs included works by Shostakovich, Hanns Eisler, Elsa Barraine, and André Jolivet. Arthur Honneger and Georges Auric, who composed two songs for the series, wrote the songs included in

\footnotetext{
${ }^{28}$ Hamelin, Femmes en prison, 193-198. Her Appendix 9 also confirms that about 50\% of the "droits politiques" prisoners were between the ages of 17 and 35 .

${ }^{29}$ Reynaud, Livre-Mémorial des déportés. Reynaud was able to identify birthdates for 97 of the 102 women on the final deportation train out of Paris. The youngest woman was 16 at the time of her deportation, the oldest 57 . The average age was 33.4 years old, with the majority of women between 21 and 35 .

${ }^{30}$ For more on the Chants du Campeur series, which includes both of these songs, see Lucie Kayas, André Jolivet (Paris: Fayard, 2005), 236ff.; and Colin Roust, "Reaching a Plus Grand Public: Georges Auric as Populist," Musical Quarterly 95, no. 2 (2012): 343-67.
} 
Famery's book. Both have texts by Paul Vaillant-Couturier, an influential writer and politician recognized worldwide for his role in promoting socialism and later communism; he was famously credited for playing a role in the development of four separate communist movements, in Russia, Germany, China, and France. That these songs entered the camp song repertoire only six years before Famery recorded their lyrics suggests the youthfulness of the women who introduced these songs to the chorus, who were the right age to have been either campers or counselors in the late 1930s. Other songs from the camping repertoire include several folk songs and the "Chant des adieux" which is traditionally sung at the end of Scouting events in France. ${ }^{31}$ Closely related to the camp songs is the "Hymne à la joie," sung to the tune of the "Ode to Joy." The text here is significant since this is the version written by Maurice Bouchor for Chants Populaires pour les Ecoles, "Oh quel rêve magnifique." 32 Originally published in 1902, this version was widely used in schools and the Scouting Movement in France during the 1930s and 1940s.

Some of the songs that circulated in the summer camps have origins in the folk and popular music of the Soviet Union. Two such examples in Famery's songbook are "Les Moissonneurs" and "Vive la vie," which were both composed by Isaak Dunayevsky for Soviet film musicals. The former circulated in France in a recording distributed by the communist label Chant du Monde, with Dunayevsky himself conducting the State Chorus and Orchestra of the Soviet Union. Though both songs had communist origins, they were not necessarily heard in a political context. Bernard Roussel, of the Ecole Pratique des Hautes Etudes in Paris, learned "Les Moissonneurs" at an unaffiliated summer camp in 1945. Based on his account, the song seems to have transcended its Soviet origins and was sung at all of the summer camps regardless of political or religious affiliations. "Vive la vie," on the other hand, was a favorite primarily amongst the communist Resistance networks and is one of the most frequently referenced songs in postwar accounts by members of the Resistance. In Les Inconnus de la Résistance, a volume of anecdotes from rank-and-file members of the French Resistance collected by the newspaper Humanité, this song is referenced more frequently than any other except "La Marseillaise." ${ }^{34}$ Originally composed by Dunayevsky for the 1934 film musical Veselye Rebyata (released in the United States under two different titles, Moscow Laughs and Jolly Fellows), the song raced to popularity in the Soviet Union and in communist circles, since it was known to be one of Stalin's favorites. ${ }^{35}$

Two Soviet folk songs also appear in Famery's songbook, "Stenka Razine" and "Souliko." The former tells the story of a Cossack leader, Stenka Razin, who in 1670-71 led a rebellion against Tsar Alexei I. The tune has long been a part of Russian folklore, though the text ("Volga-Volga mat' rodnaya") was only added in 1883 by Dmitri Sadovnikov. In 1938, the song gained new popularity thanks to the Grigori Aleksandrov film comedy Volga-Volga. "Souliko" is a Georgian folk song that was a particular favorite of Joseph Stalin, who grew up in Gori and Tbilisi. Because of Stalin's affection for the song, it was widely published in the 1930s and 1940s, and was frequently included in the songbooks of the French Communist Party.

\footnotetext{
${ }^{31}$ In Jacques Sevin's Les Chansons des Scouts de France (Paris: Editions Spes, 1932), the song is referred to as "Le Joyeux aurevoir" ["The Joyous Farewell"] and is included in a section called "Saint patrons des scouts" ["Patron Saints of the Scouts"]. For more on "Jeunesse de France," see Christopher Moore, "Socialist Realism and the Music of the French Popular Front," Journal of Musicology 25, no. 4 (2008): 473-502.

${ }_{32}$ Maurice Bouchor, "Hymne des temps futurs" ["O quel rêve magnifique"], in Chants Populaires pour les Ecoles, vol. 5, ed. Bouchor and Julien Tiersot (Paris: Librairie Hachette, 1902).

${ }^{33}$ Email from Bernard Roussel, August 21, 2012. I am grateful to M. Roussel for helping me to identify "Les Moissonneurs."

${ }^{34}$ Floriane Benoit and Charles Silvestre, eds., Les Inconnus de la Résistance: Livre d'un Témoignage Collectif(Paris:

L'Humanité and Editions Messidor, 1984).

${ }^{35}$ Email from Yves Cohen, August 21, 2012. I am grateful to M. Cohen for helping me to identify "Vive la vie."
} 
While the twelve songs mentioned so far might at first glance appear relatively neutral in terms of politics, several of them also carry potent messages that would have resonated with the women in La Petite Roquette. For example, "Jeunesse de France" is explicit about the French Revolution and the Paris Commune bringing about "French unity." In a similar vein, "Le Campeur en chocolat" is an allegorical tale about a city boy (a thinly veiled representative of bourgeois culture) going camping for the first time. Though the boy is initially frightened by all of the animals, he is eventually welcomed into their community and they teach him about work and survival. On the other hand, the version of "Vive la vie" sung in "La Petite Roquette" is explicitly about combat: the refrain is "A song sustains us, raises us up / It guides us and leads us into combat / And a boy or girl who sings unceasingly / Will triumph everywhere, always, and over everything." This first group of twelve songs reflects the women's youthfulness and, undoubtedly, helped to lift their spirits. But they also carried messages of communal solidarity and militancy.

The remaining ten songs in Faméry's book have more blatant political connotations, since all of them have specific connections to the Stalin's Five-Year Plans or to the Soviet military. All of the songs have been translated from Russian to French, though some of the translations are very loose, others have completely new texts, and in still others the title appears to have been changed. Consequently, some of these songs are tentatively or vaguely identified.

The first two, "Magnitogorsk" and "Komsomolsk," are related to specific places that were important during Stalin's reign. Magnitogorsk is an industrial town in the Chelyabinsk Oblast that has benefited from the unusually rich iron deposits in the area. During the 1930s, Magnitogorsk featured prominently in Stalin's Five-Year Plans, as he aimed to rapidly increase steel production there. Some of the construction work was done by the Soviet youth organization Komsomol, and their efforts were captured in Joris Ivens's 1933 film Komsomolsk (also released as Youth Speaks and Song of Heroes). The song "Magnitogorsk" in Famery's songbook seems to be an adaptation of one of several folk songs from the Urals used in Hanns Eisler's score (perhaps even the "Magnitogorsk Song" that is heard in the final scene). ${ }^{36}$ Komsomol was also involved in numerous other construction projects across the Soviet Union and, consequently, there are at least six villages or cities named Komsomolsk. ${ }^{37}$ The origin of this particular song "Komsomolsk" is more difficult to trace. Based on the other songs in Famery's book, it seems possible that this is a very loose French translation of a Soviet film song. ${ }^{38}$ It may also be a completely new version of the Soviet revolutionary song “By the Valleys and the Hills” (“По долинам и по взгорьям"); the structure of the text fits that song well, but apart from the first line ("Par les prés et les vallées"), the content is completely different.

Also difficult to identify are "Quand nous marchons" and "Ce que répond la camarade Fideleiv," which are both militant marching songs, describing, respectively, the October Revolution and the impending civil war between the proletariat and the bourgeoisie. "Le chant des survivants" and "Le chant du Turkmenistan" would have both had a special—and perhaps all too real—significance for the women in La Petite Roquette. "Le chant des survivants" was composed in memory of a revolutionary student named Tchernichev, who was remembered by French communists for being tortured to death in prison

\footnotetext{
${ }^{36}$ Albrecht Betz, Hanns Eisler: Political Musician (Cambridge, UK: Cambridge University Press, 1982), 114-15.

${ }^{37}$ Komsomolsk-on-Dnieper is in Ukraine; Komsomolsk-on-Amur is in Russia's far-eastern Khabarovsk Krai province; Komsomolsk is in the western Ivanovo Oblast province; and there are smaller communities called Komsomolsk in other provinces, most notably in the Siberian provinces of Kemerovo Oblast and Tomsk Oblast.

${ }^{38}$ Dmitri Shostakovich composed a song called "Komsomolsk" that was used in the 1936 film La Vie est à nous, produced by the French Communist Party.
} 
during one of the revolutions in Russia. The first verse is a call to victory, the second recalls Tchernichev as a martyr, while the final is a call for vengeance. "Le chant du Turkmenistan" might as well be an anthem for resistance. Translated, the text reads:
O wind of our liberty
You blow on humanity
Comrades, let's sing
Winter is fleeing, spring is here
We bring to the whole world
The greetings of workers
Wealth to the indigent
That is just and the spring
We liberate our country
No more prisons, no more enemies
Our dear Turkmenistan
You flourish anew, it is spring.

The final four songs were drawn from the repertoire of the Red Army, with two each representing the Soviet Air Forces and the cavalry. "Le chant des aviateurs" is known in English as the "Soviet Airmen's Song" or "Higher and Higher." During the war, it was particularly popular amongst the members of the Young Communist League. Of the songs about the cavalry, "Cavaliers de la Steppe” is particularly striking because the lyrics are so different from the French version popularized by the actor and singer Armand Mestral. Those lyrics were written by Francis Blanche and removed all traces of the Red Army. The version sung in La Petite Roquette begins almost identically to the original Russian lyrics, penned by Victor Goussev in 1934, though the subsequent verses diverge considerably (see figure 11).

Lyrics from Famery's Songbook

Plaine, ma plaine

Plaine, mon immense plaine

Passent, passent par la plaine

Tous les cavaliers de l'armée rouge, oh!

Filles s'éplorent

Filles, pauvres filles pleurent

Partent, partent pour la guerre

Tous leurs beaux amis de l'armée rouge, oh!

Translation

Plain, my plain

Plain, my immense plain

Passing, passing through the plain

All the knights of the Red Army, oh!

Daughters weep

Daughters, poor daughters cry

Leaving, leaving for the war

All their good friends of the Red Army, oh!
Lyrics by Francis Blanche

Plaine, ma plaine,

Plaine, ô mon immense plaine

Où traîne encore le cri des loups

Grande steppe blanche de chez nous

Plaine, ma plaine,

Dans l'immensité de neige,

Entends-tu le pas des chevaux

Entends-tu le bruit de ces galops

Translation

Plain, my plain,

Plain, oh my immense plain

Where the cry of the wolves still lingers

Great white steppe that is our home

Plain, my plain,

In the immensity of snow,

Do you hear the horses' steps?

Do you hear the sound of that galloping?

Figure 11: Comparison of lyrics for "Cavaliers de la Steppe." Translations by the author. 
For the women resistants in La Petite Roquette, the music that mattered to them fell into two groups. The first includes songs of their youth, including selections that the women would most likely have learned in school, at summer camps, or in the Scouting movement. The second includes militant Soviet songs, which the women would most likely have learned from their involvement in the French Communist Party or in communist-affiliated Resistance networks. Undoubtedly, the first group of songs lifted their spirits by offering some of the nostalgic comforts of home, which gave them an opportunity to momentarily forget about the overcrowded cells and the ever-present gaze of the panopticon of the prison's tower. Summer camp songs, such as "Les 3 princesses" and "Le bon vent," were markers of a happier, simpler time that provided a way to dispel the darkness into which they had been thrust. These songs were also a statement of their French identity, and thus an act of defiance against the Occupation. On the other hand, communist songs such as "Vive la vie," the "Chant du Turkmenistan," and "Stenka Razine" were explicit declarations of their political identity. At a time when it was illegal to be communist, the act of singing these militant songs was an extension of the Bastille Day and November 11 demonstrations organized in the prison in 1941 and 1942. The nuns' use of sticks to break up the afternoon gatherings of the chorus was surely a response to the strident and provocative nature of these songs.

Though current scholarship still tells us little about the songs sung by the rest of the French Resistance, the performances of these songs in the courtyards of La Petite Roquette are similar to the numerous accounts of singing by those who survived the German concentration camps. ${ }^{39}$ The French survivors of those camps consistently emphasized that no matter how dark their situations became, they faced it with a smile. Writing in 1945, one Auschwitz survivor noted that "a cheerful attitude is the best cure for Krautitis." ${ }^{40}$ Survivors of Auschwitz and Ravensbrück have both reported on the rebellious laughter of French women in those camps. ${ }^{41}$ French women in the camps also took advantage of many opportunities to commit small acts of sabotage and to be insubordinate to their guards. Survivors of Beendorf and Ravensbrück wrote that the French prisoners in those camps intentionally broke ranks and formations, marched intentionally out of step, and sang their own songs rather than the marching songs demanded by their SS guards. ${ }^{42}$ One other survivor noted, "The day we form up in ranks the minute we are told to do so will be the day there's no hope for us. It will mean that the camp has beaten us and that we're devoid of any character." 43

For the women resistants in La Petite Roquette, as for the French women in concentration camps, music became one of the most important tools at their disposal. It was an essential and vital diversion, but also a tool of resistance at a time when they were no longer able to take direct, physical action against the Occupation. They could not sabotage factories and rail lines, or blow up bridges, but they could unite into a single political body to refresh their ideals, inspire their comrades, and challenge the authorities. For

\footnotetext{
${ }^{39}$ A representative bibliography of these accounts has been assembled by the United States Holocaust Memorial Museum, http://www.ushmm.org/research/library/bibliography/?lang=en\&content=daily life.

${ }^{40}$ Odette Améry and Georges Martin-Champier, Nuit et brouillard (Paris: Editions Berger-Levrault, 1945), 90. This passage and those cited in the next three footnotes are translated in Margaret Anne Hutton, Testimony from the Nazi Camps: French Women's Voices (New York: Routledge, 2004).

${ }^{41}$ Ana Novac, Les beaux jours de ma jeunesse (Paris: Julliard, 1968; repr. Paris: Balland, 1996), 222; Josette de Mori-Perrin, Pour que demain soit liberté (Autun: Imprimerie Pelux, 1992), 132.

${ }^{42}$ Raymonde Guyon-Belot, Le Sel de la mine (Paris: France-Empire, 1990), 174-75; Jackye Brun, Jusqu'au rivage des morts (Paris: La Pensée universelle, 1979), 143.

${ }^{43}$ Solange Blanc, Femmes à tuer (Paris: La Pensée universelle, 1984), 119.
} 
these women resistants, communal singing became their primary means of taking action against the Occupation.

\section{Bibliography}

Améry, Odette and Georges Martin-Champier. Nuit et Brouillard. Paris: Editions Berger-Levrault, 1945.

Barbaroux, Marie-Noelle, and Jocelyne Broussard. "L'évolution historique de La Petite Roquette." Rééducation 191 (May 1967): 2-41.

Barthoulot, Thierry. Paroles et musique: Les Chansons et la Deuxième guerre mondiale. Besançon: Musée de la Résistance et de la Déportation, 2003.

Benoit, Floriane, and Charles Silvestre, eds. Les Inconnus de la Résistance: Livre d'un Témoignage Collectif. Paris: L'Humanité and Editions Messidor, 1984.

Bentham, Jeremy. The Panopticon Writings. Edited by Miran Bozovic. London: Verso, 1995.

Betz, Albrecht. Hanns Eisler: Political Musician. Cambridge, UK: Cambridge University Press, 1982.

Blanc, Solange. Femmes à tuer. Paris: La Pensée universelle, 1984.

Brun, Jackye. Jusqu'au rivage des morts. Paris: La Pensée universelle, 1979.

Foucault, Michel. Discipline and Punish: The Birth of the Prison. Translated by Alan Sheridan. New York: Vintage Books, 1995.

- Psychiatric Power: Lectures at the Collège de France, 1973-1974. Edited by Jacques Lagrange.

Translated by Graham Burchell. New York: Picador, 2006. http://dx.doi.org/10.1057/9780230245068

Fulcher, Jane. "French Identity in Flux: The Triumph of Honegger's Antigone." Journal of

Interdisciplinary History 36 (Spring 2006): 649-74. http://dx.doi.org/10.1162/jinh.2006.36.4.649

—_ ed.. Reconfiguring Identity: Musical Culture and Creativity in France during the German Occupation. Forthcoming.

Gaillac, Henri. Les Maison de correction, 1830-1945. Paris: Editions Cujas, 1991.

Guyon-Belot, Raymonde. Le Sel de la mine. Paris: France-Empire, 1990.

Hamelin, France. Femmes dans la nuit: L'Internement à La Petite Roquette et au Camp des Tourelles, 1943-1944. Paris: Renaudot, 1988.

. Femmes en prison dans la nuit noir de l'occupation: Le Dépôt, La Petite Roquette, le Camp des Tourelles. Paris: Editions Tirésias, 2004.

Hutton, Margaret Anne. Testimony from the Nazi Camps: French Women's Voices. New York: Routledge, 2004.

Jackson, Julian. France: The Dark Years 1940-1944. Oxford: Oxford University Press, 2001. http://dx.doi.org/10.1093/acprof:oso/9780198207061.001.0001

Kayas, Lucie. André Jolivet. Paris: Fayard, 2005.

Krivopissko, Guy, and Daniel Virieux. "Musiciens: Un profession en résistance?” In La Vie musicale sous Vichy, ed. Myriam Chimènes. Paris: Editions Complexe, 2001.

Lucas, Charles. Du systemme pénitentiaire en Europe et aux Etats-Unis: Ouvrage dédié aux Chambres, précédé d'une pétition qui leur est addressée et orné de plusieurs plans de prisons et tableaux statistiques. 2 vols. Paris: Editions A. Bossange and Editions Charles Béchet, 1828-1830. 
Moore, Christopher. "Socialist Realism and the Music of the French Popular Front." Journal of Musicology 25, no. 4 (2008): 473-502. http://dx.doi.org/10.1525/jm.2008.25.4.473

Mori-Perrin, Josette de. Pour que demain soit liberté. Autun: Imprimerie Pelux, 1992.

Novac, Ana. Les beaux jours de ma jeunesse. Paris: Julliard, 1968. Reprint, Paris: Balland, 1996.

Reynaud, Michel, ed. Livre-Mémorial des déportés de France arrêtes par mesure de repression et dans certains cas par mesure de persecution, 1940-1945. Paris: Editions Tirésias, 2004.

Roust, Colin. "Reaching a Plus Grand Public: Georges Auric as Populist.” Musical Quarterly 95, no. 2 (2012): 343-67. http://dx.doi.org/10.1093/musqtl/gds005

__ "Sounding French: The Film Music and Criticism of Georges Auric, 1919-1945." PhD diss., University of Michigan, 2007.

. "Toward an Aesthetic of Resistance: Georges Auric's Quatre Chants de la France malheureuse." Ars Lyrica 18 (2009): 157-72.

Semard, Yvette. En souvenir de l'avenir: Au jour le jour dans les camps de Vichy (1942-1944). Montreuil: L'Arbre Verdoyant, 1991.

Simeone, Nigel. "Making Music in Occupied Paris.” Musical Times, no. 1894 (2006): 23-50. . "Messiaen and the Concerts de la Pléiade: 'A Kind of Clandestine Revenge against the Occupation!”” Music and Letters 81, no. 4 (2000): 551-84. http://dx.doi.org/10.1093/ml/81.4.551

Virieux, Daniel. “Front National des Musiciens (printemps 1941-automne 1944).” In Roger Désormière, 1898-1963: Actes du colloque, ed. Nicolas Guillot. Paris: Comité pour la celebration du centenaire de la naissance de Roger Désormière, 1999.

- "Le Front national de lute pour la liberté et l'indépendance de la France: Un mouvement de résistance, période clandestine (mai 1941-août 1944).” Thèse de doctorat, Université de Paris 8 , 1995. 